\title{
Impact of multiplexed respiratory viral panels on infection control measures and antimicrobial stewardship: a review of the literature
}

\author{
Jense Wils ${ }^{1} \cdot$ Veroniek Saegeman $^{1} \cdot$ Annette Schuermans $^{1}$
}

Received: 6 April 2021 / Accepted: 3 November 2021 / Published online: 20 November 2021

(c) The Author(s), under exclusive licence to Springer-Verlag GmbH Germany, part of Springer Nature 2021

\begin{abstract}
Multiplexed respiratory viral panels (MRVP) have recently been added to the diagnostic work-up of respiratory infections. This review provides a summary of the main literature of MRVP for patients with regard to 3 different topics. Can the results of MRVP reduce the inappropriate use of antibiotics, can they guide the use of appropriate antiviral therapy and do they have an added value with respect to infection control measures? Literature was searched for based on a defined search string using both the PubMed and Embase database. Twenty-five articles report on the impact of MRVP on antibiotic therapy. In all the articles where active antimicrobial stewardship was performed (e.g., education/advice on interpreting results of MRVP) $(N=9)$, a reduction in antibiotic therapy was shown (with exception of 2 studies). Three studies evaluating the effect of MRVP on antimicrobial use in a population that is not suspected of having bacterial pneumonia (e.g., absence of radiology suggestive for bacterial infection or low PCT) found a positive impact on antibiotic therapy. Eight studies with a short TAT $(<7 \mathrm{~h})$ had a positive impact on use of antibiotic therapy. Eleven studies focused on the impact of MRVP on antiviral use. In contrast to antibiotic reduction, all studies systematically objectified improved antiviral use as a consequence of MRVP results. With regard to the impact of MRVP on infection control, eleven articles were withheld. All these studies led to a more accurate use of infection control measures by detecting unidentified pathogens or stopping isolation precautions in case of a negative MRVP result. MRVP don't reduce antibiotic therapy in all populations. Reduction seems more likely if the following factors are present: active antimicrobial stewardship, low likelihood of a bacterial infection, and a short turnaround time to result. With respect to antiviral therapy, all studies have an impact but the targeted use of antivirals is so far not that evidence based for all viral respiratory pathogens. Regarding infection control measures, the potential impact of MRVP is high because of the need of additional isolation precautions for many respiratory viruses, although logistical problems can occur.
\end{abstract}

Keywords Respiratory $\cdot$ Multiplex $\cdot$ Infection control $\cdot$ Antimicrobial stewardship

\section{Introduction}

Respiratory infections are considered among the most important type of infections with an enormous impact on society [1]. This impact is reflected in the large number of hospital visits for both adults and children, where respiratory viral infections (RVI) are the most important reason to seek medical care [2,3]. The diagnostic work up of these infections has changed tremendously

Jense Wils

jensewils1987@gmail.com

1 Department of Infection Control, UZ Leuven, Leuven, Belgium over the last decades. With regard to laboratory diagnostics specifically, molecular methods have been added to the conventional laboratory diagnostics such as culture and antigen detection. Furthermore, the development of new molecular technologies has improved the capability to simultaneously detect multiple targets in a single run $[4,5]$. Because these multiplexed respiratory viral panels (MRVP) are relatively new, the medical world is struggling with the proper actions to take based on the information yielded by these tests. The added value to improve insights into the epidemiology of RVI seems irrefutable [6]. However, the exact added clinical value of these tests seems less straight forward. This review tries to provide a summary of the main literature of 
MRVP with regard to 3 different topics. Can the results of MRVP reduce the inappropriate use of antibiotics? When is there a significant impact of MRVP on antiviral therapy? What is the added value of MRVP with respect to infection control?

\section{Methods}

We performed a literature search on August 21th, 2021, using the PubMed and Embase database and included articles published before January 1st, 2021. The search strings that were used are provided in Table 1. The PubMed search resulted in 636 articles, and the Embase search resulted in 659 articles. After removal of duplicates, 1145 articles were withheld. These articles were subjected to the inclusion and exclusion criteria presented in Table 1. Additional articles were found using backward and forward citation tracking.

\section{Results}

The results are presented in Table 2 . Twenty-five articles ( $N=16$ for adults, $N=5$ for children, $N=4$ for mixed population) report on the impact of MRVP on antibiotic therapy. In all the articles where active antimicrobial stewardship was performed (e.g., education/advice on interpreting results of MRVP) $(N=9)$, a reduction in antibiotic therapy was shown (with exception of 2 studies). Three studies evaluating the effect of MRVP on antimicrobial use in a population that is not suspected of having bacterial pneumonia (e.g., absence of radiology suggestive for bacterial infection or low PCT) found a positive impact on antibiotic therapy. Eight studies with a short TAT $(<7 \mathrm{~h})$ had a positive impact on use of antibiotic therapy.

Eleven studies ( $N=8$ for adults, $N=3$ for mixed population) focused on the impact of MRVP on antiviral use. In contrast to antibiotic reduction, all studies systematically objectified improved antiviral use as a consequence of MRVP results.

With regard to the impact of MRVP on infection control, eleven articles ( $N=5$ for adults, $N=4$ for children, $N=2$ for mixed population) were withheld. All these studies led to a more accurate use of infection control measures by detecting unidentified pathogens or stopping isolation precautions in case of a negative MRVP result. An overview of respiratory viruses commonly included in MRVP, and their recommended isolation precautions is summarized in Table 3.

Table 1 Search string, inclusion, and exclusion criteria

Search string

PubMed:

(“Adolescent, Hospitalized”[Mesh] OR “Child, Hospitalized"[Mesh] OR patient) AND (“Multiplex Polymerase Chain Reaction"[Mesh] OR "Multiplex Ligation Dependent Probe Amplification" OR "Multiplex Ligation-Dependent Probe Amplification" OR "PCR Multiplex" OR "Multiplex PCR") AND (“Infection Control”[Mesh] OR “infection control” OR "Hospitals, Isolation”[Mesh] OR "Patient Isolation”[Mesh] OR "Patient Safety" OR Safety OR isolation OR "Anti-Infective Agents"[Mesh] OR "Anti Infective Agents" OR "Antiinfective Agents" OR Antiinfective OR Microbicides OR Antimicrobial OR "Anti-Microbial Agents" OR "Anti Microbial Agents" OR "Anti-Bacterial Agents"[Mesh] OR Antibiotic OR Antibiotics OR "Anti-Bacterial Compounds" OR "Anti Bacterial Compounds" OR "Anti Bacterial Agents" OR "Antibacterial Agents" OR "Bacteriocidal Agents" OR Bactericides OR "Antiviral Agents”[Mesh] OR "Antiviral Drugs" OR Antivirals OR antiviral) AND (Respiratory OR "Respiratory Tract Diseases"[Mesh])

Embase:

('hospitalized adolescent'/exp OR 'hospitalized child'/exp OR patient) AND ('multiplex polymerase chain reaction'/exp OR "Multiplex Ligation Dependent Probe Amplification" OR "Multiplex Ligation-Dependent Probe Amplification" OR "PCR Multiplex" OR "Multiplex PCR") AND ('infection control'/exp OR "infection control" OR 'isolation hospital'/exp OR "patient isolation'/exp OR "Patient Safety" OR Safety OR isolation OR 'antiinfective agent'/exp OR “Anti Infective Agents” OR “Antiinfective Agents” OR Antiinfective OR Microbicides OR Antimicrobial OR "Anti-Microbial Agents" OR "Anti Microbial Agents" OR "anti-bacterial agents" OR Antibiotic OR Antibiotics OR "Anti-Bacterial Compounds" OR "Anti Bacterial Compounds" OR "Anti Bacterial Agents" OR "Antibacterial Agents" OR "Bacteriocidal Agents" OR Bactericides OR 'antivirus agent'/exp OR "Antiviral Drugs" OR Antivirals OR antiviral) AND (Respiratory OR 'respiratory tract disease'/exp)

Inclusion and exclusion criteria:

(1) The study must report on the impact of MRVP on infection control measures and/or antimicrobial stewardship.

(2) The MRVP had to obtain information regarding at least 2 different viruses (and less than 6 bacteria.)

(3) Quantitative (non-)randomized studies, quantitative descriptive studies (including case reports), qualitative studies, (systematic) reviews and meta-analysis were all included provided that they were published in a peer reviewed journal. Conference proceedings and personal narratives were excluded.

(4) Studies written in English were considered.

(5) Studies conducted in developing countries were excluded. 


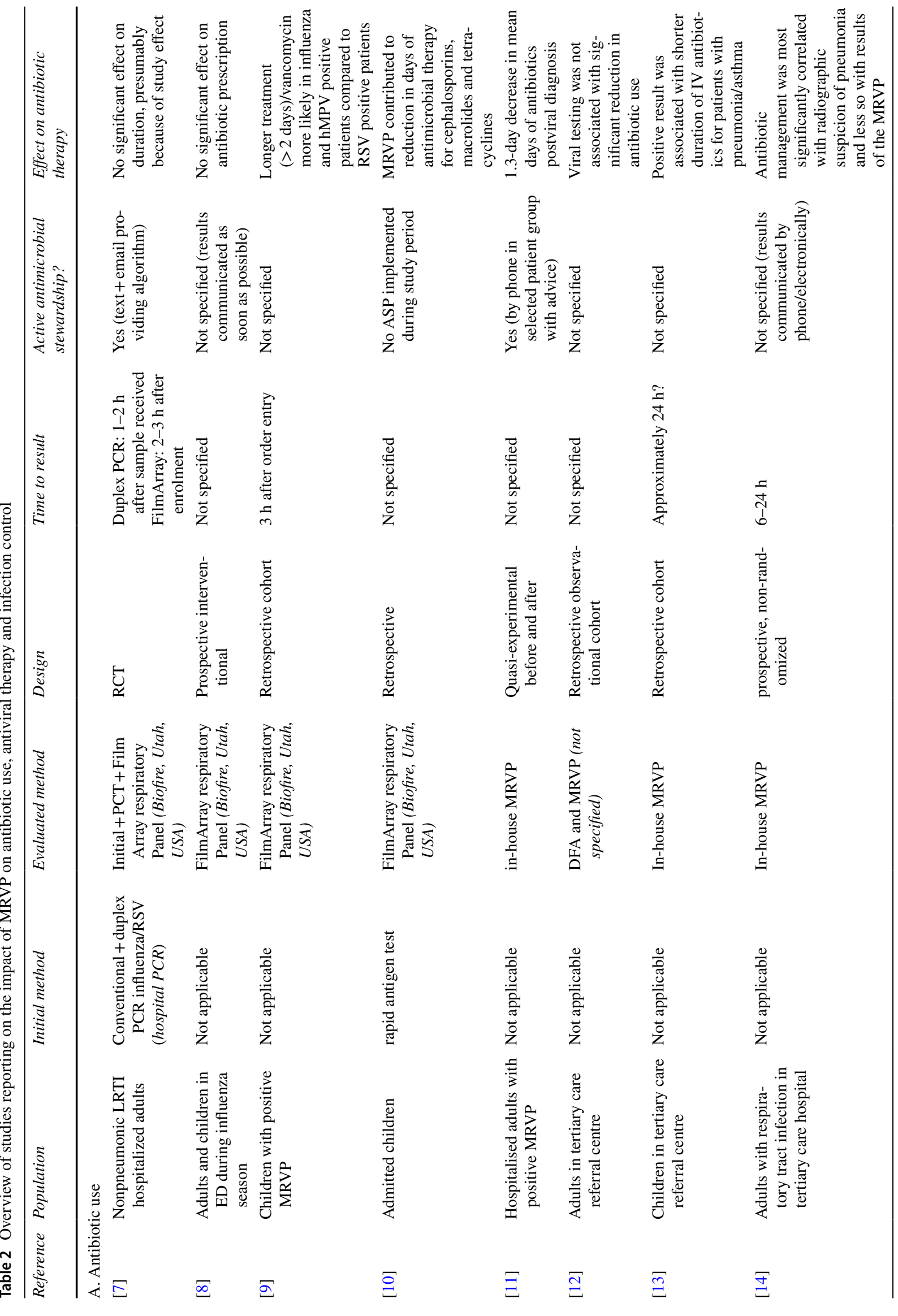




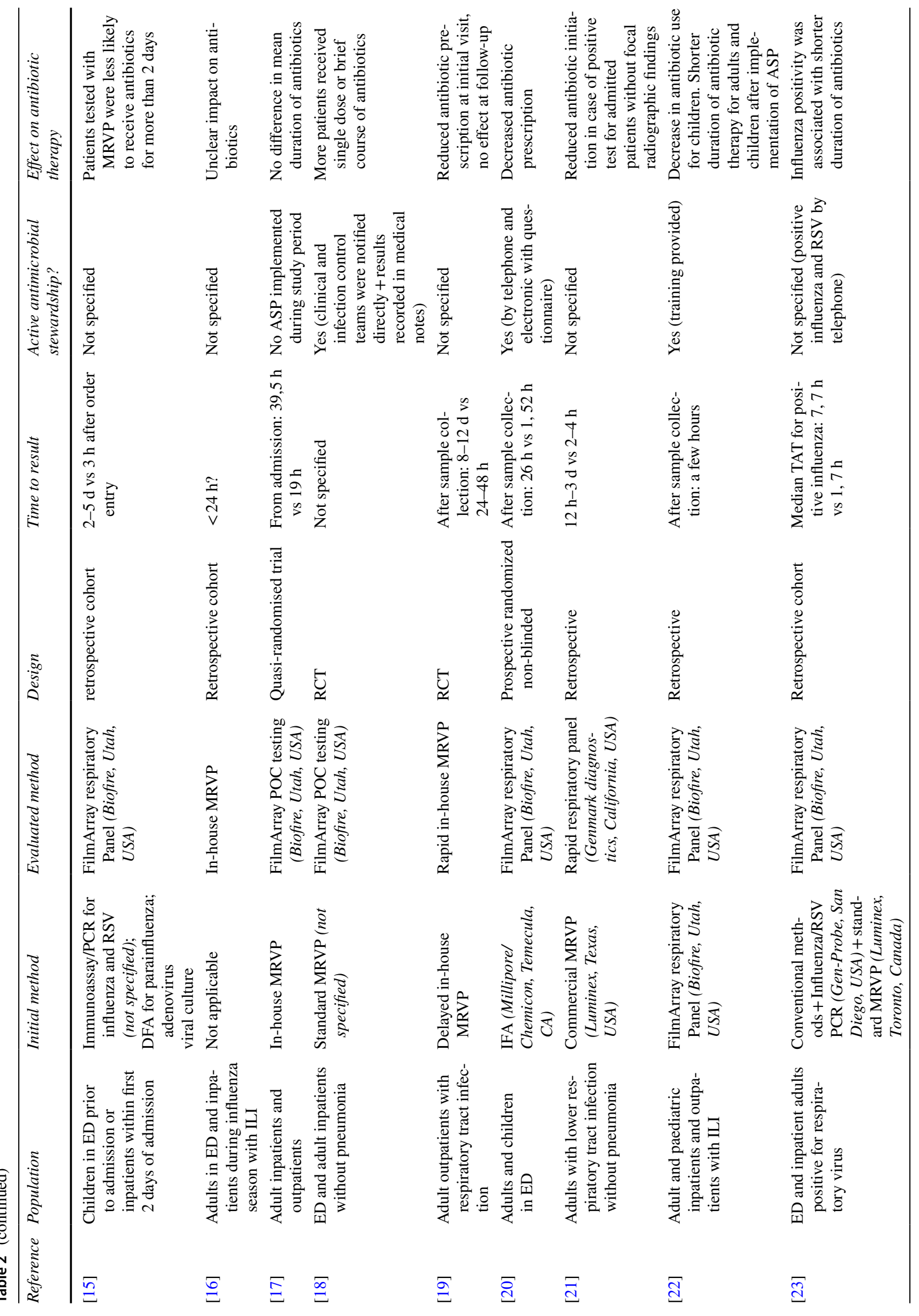




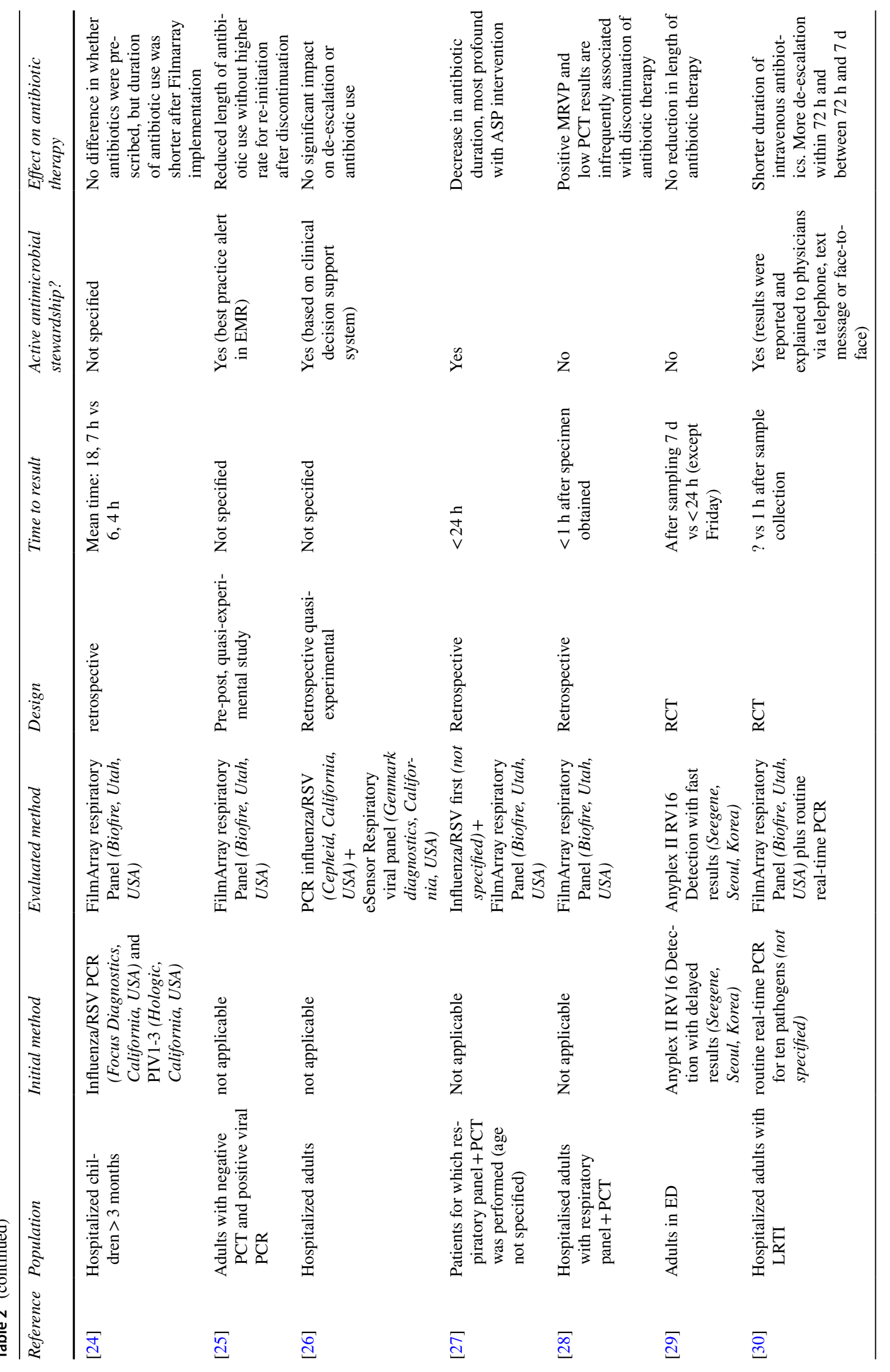




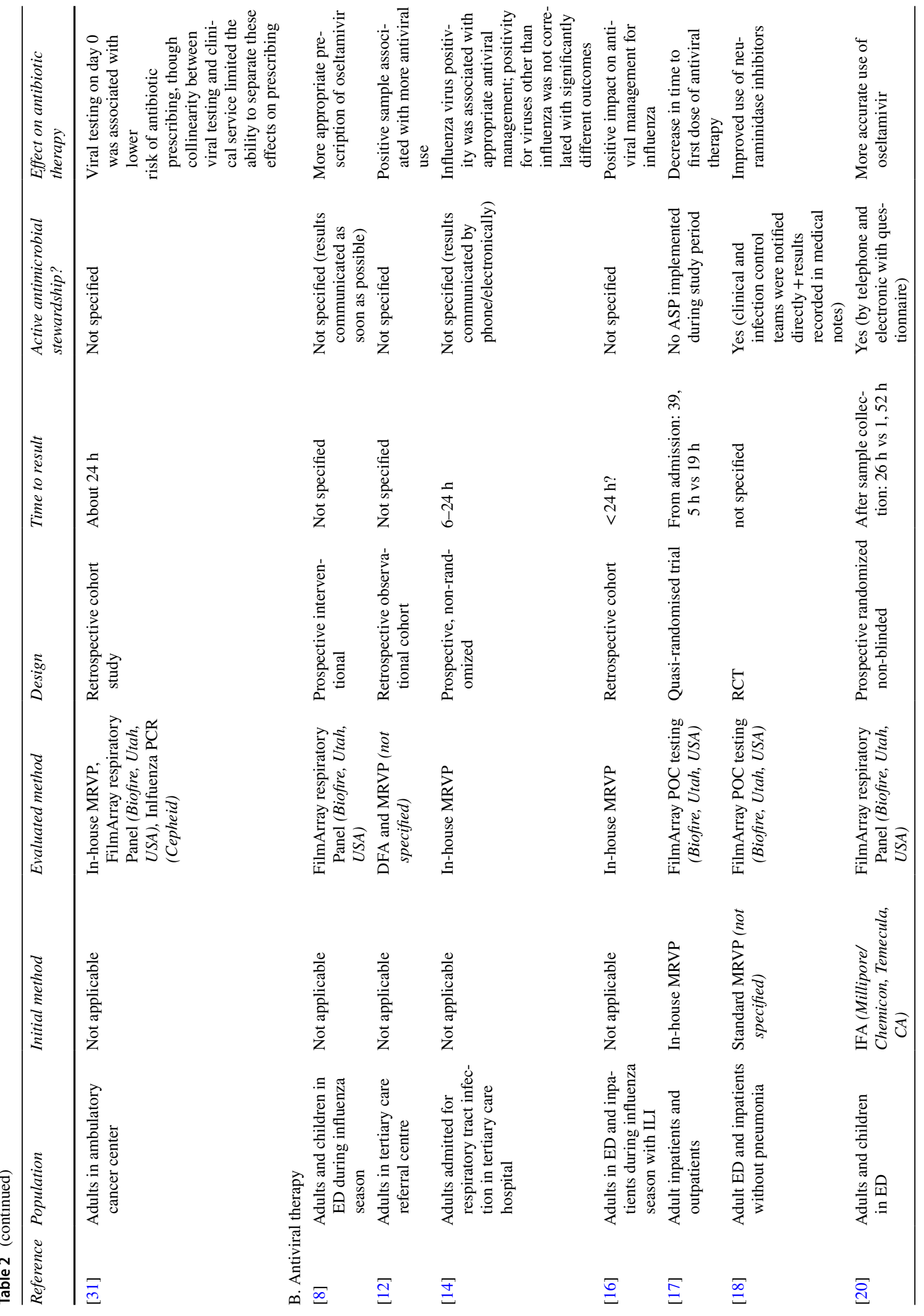




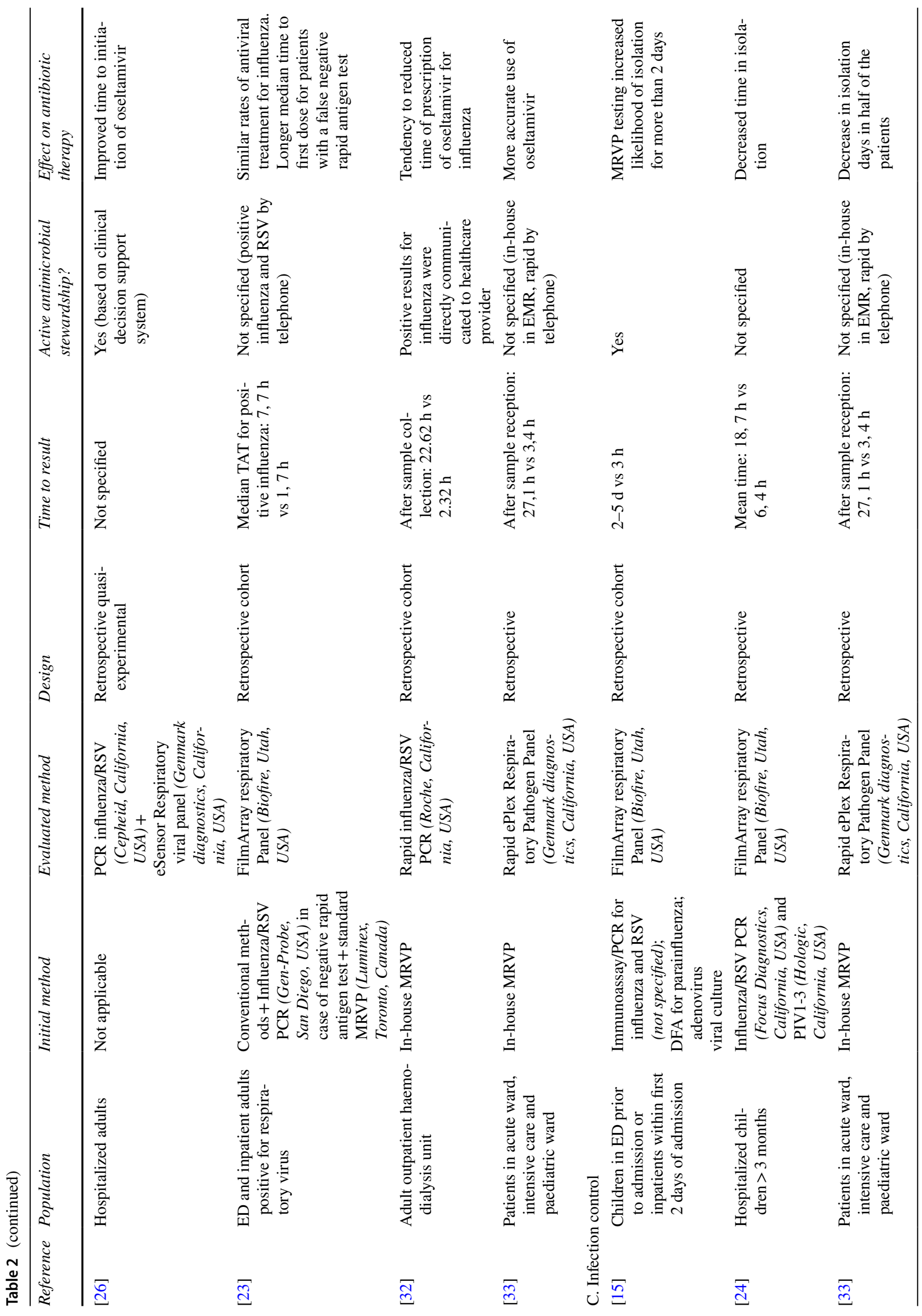




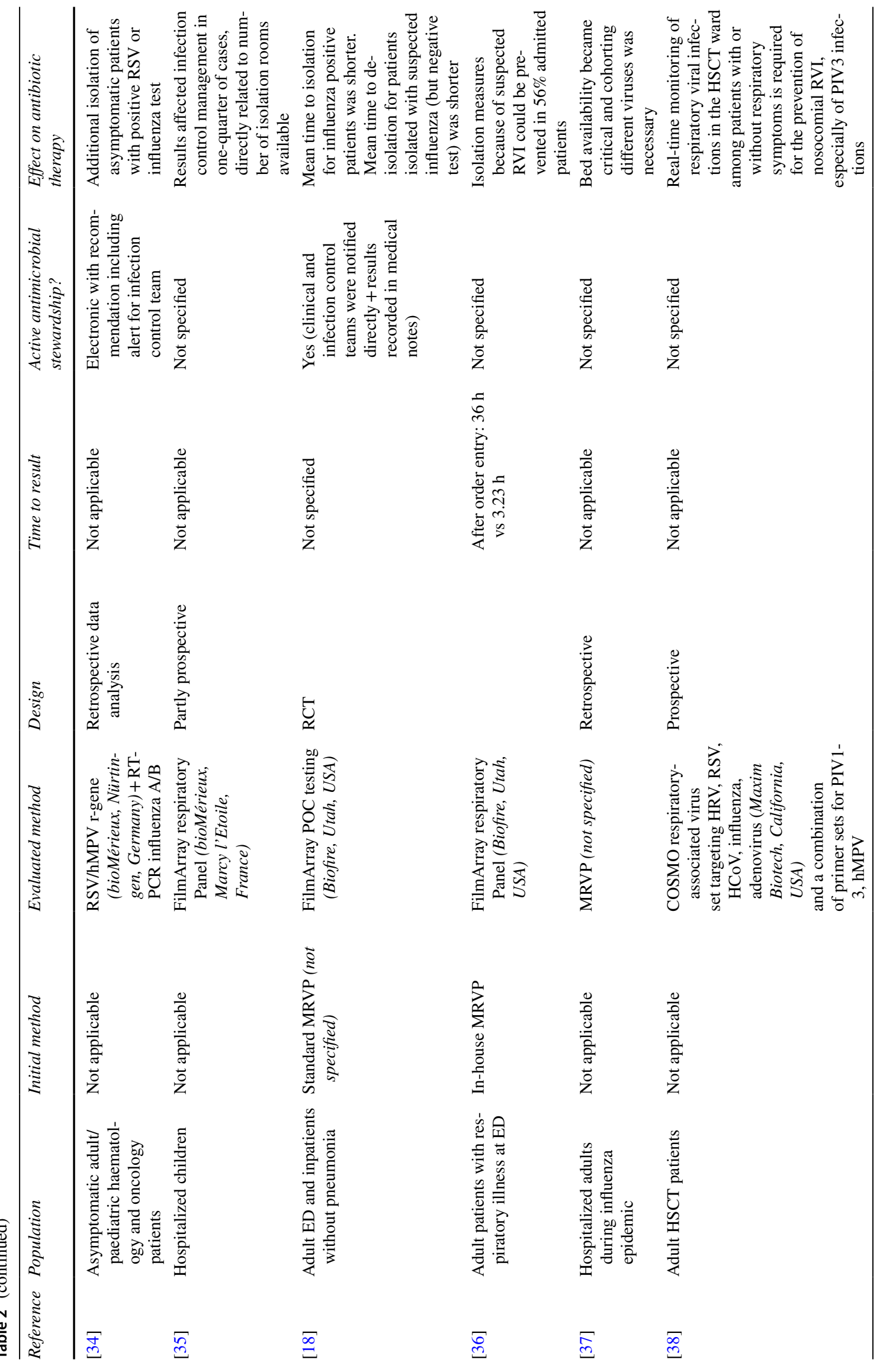




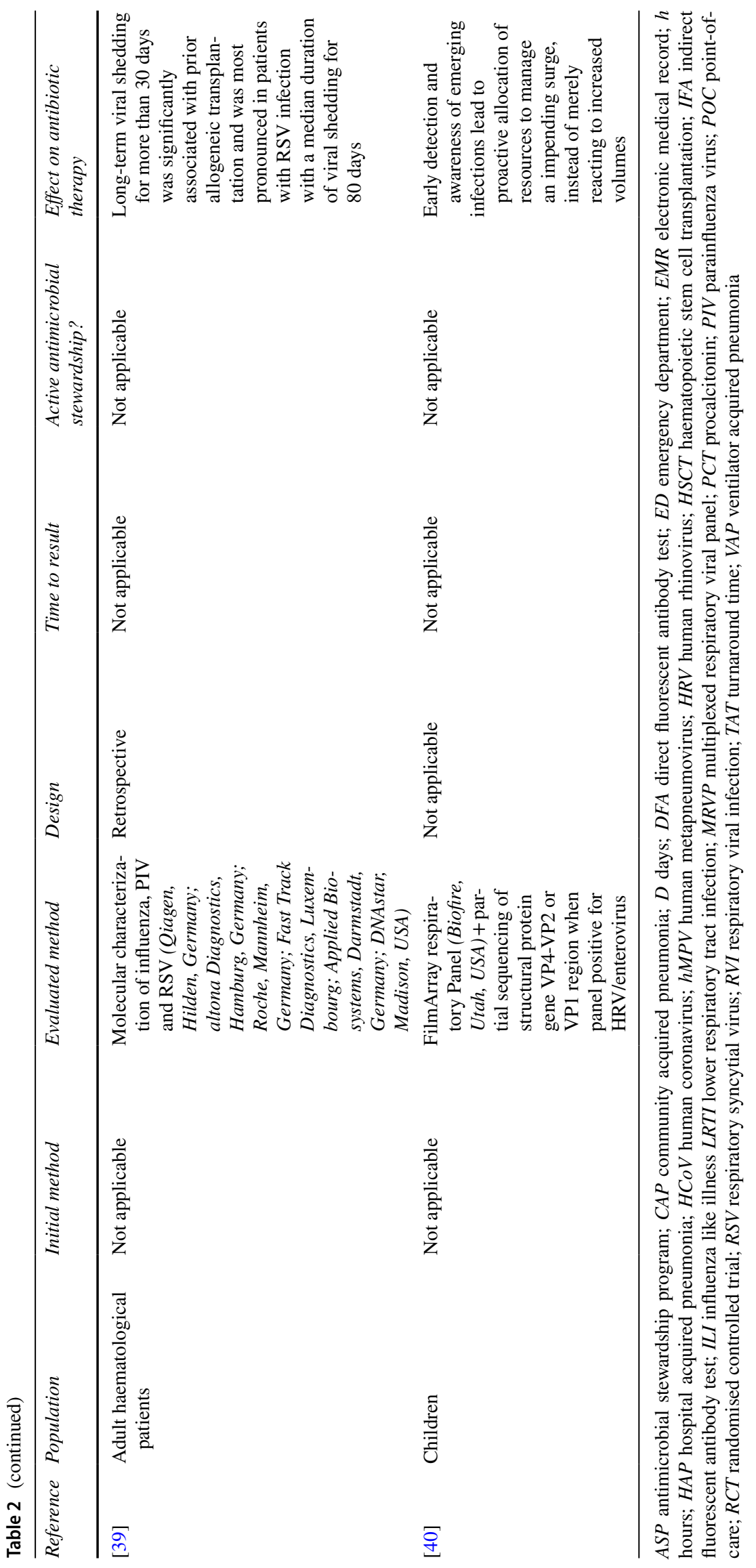


Table 3 Recommended isolation precautions for different viruses when detected in respiratory samples

\begin{tabular}{llll}
\hline & $\mathrm{CDC}$ & $\mathrm{WHO}$ & $\mathrm{LCI}$ \\
\hline Middle East respiratory syndrome coronavirus & $\mathrm{S}+\mathrm{C}+\mathrm{A}$ & $\mathrm{S}+\mathrm{C}+\mathrm{A}+(\mathrm{D})$ & $\mathrm{S}+\mathrm{C}+\mathrm{A}$ \\
Severe acute respiratory syndrome coronavirus & $\mathrm{S}+\mathrm{C}+\mathrm{A}+(\mathrm{D})^{1}$ & $\mathrm{~S}+\mathrm{C}+\mathrm{A}+(\mathrm{D})$ & $\mathrm{S}+\mathrm{C}+\mathrm{A}$ \\
Human coronavirus NL63 & $\mathrm{NF}$ & $\mathrm{NF}$ & $\mathrm{NF}$ \\
Human Coronavirus HKU1 & $\mathrm{NF}$ & $\mathrm{NF}$ & $\mathrm{NF}$ \\
Rhinovirus & $\mathrm{S}+\mathrm{D} \pm \mathrm{C}^{2}$ & $\mathrm{NF}$ & $\mathrm{NF}$ \\
Human parainfluenza virus & $\mathrm{S}+\mathrm{C}^{3}$ & $\mathrm{NF}$ & $\mathrm{NF}$ \\
Human metapneumovirus & $\mathrm{S}+\mathrm{C}^{4}$ & $\mathrm{NF}$ & $\mathrm{NF}$ \\
Respiratory syncytial virus & $\mathrm{S}+\mathrm{C}+(\mathrm{D})^{5}$ & $\mathrm{NF}$ & $\mathrm{S}+\mathrm{C}+\mathrm{D}$ \\
Cytomegalovirus & $\mathrm{S}$ & $\mathrm{NF}$ & $\mathrm{NF}$ \\
Herpes simplex virus & $\mathrm{NF}$ & $\mathrm{NF}$ & $\mathrm{NF}$ \\
Seasonal influenza virus & $\mathrm{S}+\mathrm{D}$ & $\mathrm{NF}$ & $\mathrm{S}+\mathrm{D}$ \\
Adenovirus & $\mathrm{S}+\mathrm{D}+\mathrm{C}^{7}$ & $\mathrm{NF}$ & $\mathrm{S}+\mathrm{D}+\mathrm{C}^{8}$ \\
\hline
\end{tabular}

${ }^{1}$ Airborne preferred, droplet if airborne unavailable

${ }^{2}$ Contact precautions warranted if copious moist secretions and close contact likely to occur (e.g. young infants)

${ }^{3}$ Guidelines refer to infants/young children

${ }^{4}$ Route of transmission not established, assumed to be identical to RSV

${ }^{5}$ Guidelines refer to infants, young children and immunocompromised; mask according to standard precautions

${ }^{6}$ No additional precautions for pregnant healthcare workers

${ }^{7}$ Applicable for patients with adenovirus pneumonia

${ }^{8}$ Contact and droplet isolation precautions for children younger than 6 years old and for all ages in case of adenovirus pneumonia

$A$, airborne isolation precautions; $C$ contact isolation precautions; $C D C$ Centres for Disease Control and Prevention; $D$ droplet isolation precautions; $L C I$ Landelijke Coördinatie Infectieziektebestrijding; $N F$ not found; $S$ standard precautions; $W H O$ World Health Organization

\section{Discussion}

\section{Do MRVP reduce the use of antibiotics?}

Inappropriate use of antibiotics in patients with RVI is a problem that concerns patients of all ages [41]. Antibiotic misuse not only leads to potential drug side effects, but is also associated with increasing prevalence of antibiotic resistance. Therefore, every tool that can lead to more appropriate use of antibiotics should be seized. The potential role of MRVP in this appears less straight forward than one might think. At a first glance, the results presented in Table 2 appear to be conflicting with some studies showing a reduction in antibiotic use and other studies failing to demonstrate this reduction. However, there are some interesting points to highlight. We therefore regrouped the studies according to the setting: presence of antimicrobial stewardship, patient's diagnosis as non-bacterial infection, and delay of MRVP result.

First, all the studies where active antimicrobial stewardship was performed (e.g., education/advice on interpreting results of MRVP) $(\mathrm{N}=9)$ show a reduction in antibiotic therapy, with the exception of two studies. In the first study, 300 patients hospitalized with nonpneumonic respiratory tract infections were randomly assigned at a ratio of 1:1 to receive standard care (bacterial and viral cultures and influenza/RSV duplex PCR) or procalcitonin (PCT)-guided care and MRVP (intervention group) [7]. Although there were no significant differences in antibiotic use or adverse events between intervention patients and those in the nonintervention group, subgroup analyses did reveal fewer subjects with positive results of viral testing and low PCT values who were discharged receiving antibiotics (20\% vs $45 \% ; P=0.002)$ and shorter antibiotic durations among algorithm-adherent intervention patients versus nonintervention patients ( 2.0 vs 4.0 days; $P=0.004$ ). Compared with historical controls (from 2008 to 2011), antibiotic duration in nonintervention patients decreased by 2 days ( 6.0 vs 4.0 days; $P<0.001)$, suggesting a study effect. The second study that failed to show an effect of active antimicrobial stewardship on antibiotic discontinuation used a clinical decision support system considering following factors: evaluation for concurrent bacterial infections of any source, antibiotic use for prophylaxis or an alternative indication (e.g., febrile neutropenia, chronic obstructive pulmonary disease exacerbation), noted concern for superimposed bacterial pneumonia on chart review, and type of virus isolated [26]. However, chest 
radiography was not routinely included in the assessment and the study observed a low use of PCT. The reasons for the need of antimicrobial stewardship might be multiple. Interpretation of test results is complex, because multiple factors should be taken into account. For example, the same test result might need a different action for an immunocompetent patient in comparison to an immunocompromised patient. Also, the fact that many medical doctors are on a tight schedule might sometimes lead to a lack of time to thoroughly review all results and current antibiotic therapy. To conclude the section regarding the importance of antimicrobial stewardship, we would like to highlight the findings from the study of Moradi et al. They were able to attain a significant reduction in antibiotic therapy using an electronic medical record alert to question the need for antibiotics [25]. Patients were included if they had both a positive virus on MRVP and a PCT value $<0.25 \mathrm{ng} / \mathrm{ml}$ within $48 \mathrm{~h}$ of each other and at least one active systemic antibiotic. A big advantage of this method is that the alert can be automated to occur at all times, which doesn't require active intervention of the infection control team.

Second, three studies that evaluated the effect of MRVP in a population that is not suspected of having bacterial pneumonia (e.g., absence of radiology suggestive for bacterial infection or low PCT) found a positive impact on antibiotic therapy $[18,21,25]$. This seems intuitive, since the possibility of a bacterial component most likely undermines the results of a positive MRVP. However, a study of Timbrook et al. found that a positive MRVP and low PCT were infrequently associated with discontinuation of antibiotics [28]. A possible factor explaining the lack of antibiotic discontinuation in this study is the absence of an active stewardship program.

Last, another factor that seems to play an important role is the turnaround time (TAT) of the MRVP. The Infectious Diseases Society of America and the Society for Healthcare Epidemiology of America recommends the use of rapid viral testing for respiratory pathogens to reduce the use of inappropriate antibiotics (weak recommendation, low-quality evidence) [42]. With regard to MRVP in particular, we found that most studies reporting a short TAT $(<7 \mathrm{~h})$ indeed report a positive impact on antibiotic therapy $[15,20-24,30]$. This seems intuitive, since testing closest to presentation of symptoms will most likely have the most impact on patient management. However, the study of Timbrook performed in hospitalized patients with a short TAT $(<1 \mathrm{~h})$ of the MRVP failed to show a reduction in antibiotic therapy [28]. As mentioned before, the lack of antibiotic discontinuation in this study might be attributed to the absence of an active stewardship program.

To conclude, the result of MRVP on itself is unlikely to yield a positive effect on antibiotic use. A positive effect is more likely with active antimicrobial stewardship, a low suspicion of bacterial pneumonia and an actionable TAT.

\section{Can MRVP have a significant impact on antiviral therapy?}

An important consideration to take into account when answering this question is to wander if MRVP are able to reveal the true aetiology of respiratory tract infections. The observation that respiratory viruses are detected in asymptomatic patients is evidence for the fact that the detection of a virus in symptomatic patients doesn't necessarily explain their etiological role for that patient. There are several explanations for this observation: detection of virus could represent the period of incubation before onset of symptoms, postinfectious shedding, or subclinical infection [43]. Furthermore, current laboratory practices generally report qualitative results for a MRVP, rather than determining a true viral load [44]. Of course, this also restricts the ability of the clinician to determine whether a retrieved viral pathogen is indeed the cause of the RVI. The currently available laboratory-developed viral load assays have multiple problems, including the lack of an international standard, lack of standardized technology, and lack of consensus on specimen types [44]. Additionally, the timing of specimen collection can influence viral load results [44].

Once the clinician concludes that the detected virus is indeed most likely the true pathogen, antiviral therapy can be considered. The benefit of determining the causative virus is limited by the low number of drugs that are available for the treatment of different RVI. Licensed drugs are available for influenza and respiratory syncytial virus (RSV). The CDC recommends antiviral treatment of influenza as early as possible for any patient with confirmed or suspected influenza who is hospitalized; has severe, complicated, or progressive illness; or is at higher risk for influenza complications [45]. For the first two groups, oral oseltamivir (neuraminidase inhibitor) is recommended, while other treatment options consist of other neuraminidase inhibitors (inhaled zanamivir, intravenous peramivir) and a cap-dependent endonuclease inhibitor (oral baloxavir marboxil) [45]. Importantly, decisions about starting antiviral treatment should not wait for laboratory confirmation of influenza [46]. Thus, antiviral treatment should be initiated until results of MRVP are available. Impact on antiviral treatment can be expected in 2 situations: a patient started on antiviral therapy that tests negative and a patient that qualifies for therapy but wasn't suspected of having influenza. In contrast to antibiotic reduction, this improved antiviral use as a consequence of MRVP results was systematically objectified in all eleven studies focusing on the effect on antiviral use (Table 2). Hence, the effect on antiviral therapy seems to be less dependent 
on antimicrobial stewardship, low suspicion of bacterial pneumonia, and short TAT. For treatment of RSV, the only licensed drug is ribavirin. Oral or nebulized ribavirin, alone or in combination with other interventions, may be useful for treatment of RSV in some immunocompromised individuals [47, 48]. However, it is not routinely recommended for treatment of RSV bronchiolitis in children, where supportive therapy remains the cornerstone of therapy [49].

For antiviral treatment of RVI, not caused by influenza and RSV, few options are available. Although supportive care remains the most important part of therapy for these infections, some data is available regarding antiviral treatment. However, in general, further research is needed to determine which groups of patients would benefit from antiviral therapy. Concerning adenovirus, there is limited published data available on the efficacy of cidofovir in immunocompromised patients. In lung transplant and hematopoietic stem cell transplant (HSCT) patients more specifically, cidofovir might contribute to clinical improvement and increased survival [50-52]. However, the prognosis of adenovirus pneumonia appears to remain poor despite the use of cidofovir, and there are concerns regarding nephrotoxicity of cidofovir [51, 53]. With regard to human metapneumovirus (HMPV), data on antiviral treatment is very scarce. The combination of oral and aerosolized ribavirin with polyclonal intravenous immune globulin (IVIG) seems an effective treatment for severe HMPV infections, but to our knowledge, no randomized controlled trials in humans have been performed. Despite this lack of good trials in humans, a lot of experience has been gained meanwhile in individual cases and small case series [54]. For pneumonia caused by parainfluenza viruses, case series show variable results for the use of ribavirin in transplant patients [55-58]. In contrast to ribavirin, DAS181 might be more suited for the treatment of parainfluenza virus infections in immunocompromised patients. DAS181 has been evaluated in different case series of transplant patients, but isn't available for clinical use at this moment [59]. Regarding human rhinovirus, there is no clear role for antiviral therapy in critically ill patients with rhinovirus pneumonia. This is also applicable for severe acute respiratory syndrome coronavirus (SARS-CoV), since severely ill ARDS-patients treated with ribavirin appear to benefit little from antiviral therapy [60]. With regard to middle eastern respiratory coronavirus (MERS-CoV), the combination of interferon alfa- $2 b$ and ribavirin showed $a$ beneficial effect in a retrospective cohort study of 20 patients [61]. As for pneumonia caused by other viruses, diagnosing viral pneumonia by Herpesviridae remains a diagnostic challenge. Obtaining evidence of cytopathic effects is hard to obtain and not sensitive, while detection of Herpesviridae with viral culture or PCR doesn't differentiate active infection from asymptomatic shedding. For herpes simplex virus type 1 (HSV-1), a viral load in bronchoalveolar fluid above 100000 copies/mL was significantly associated with critical features (e.g., admission to ICU, mechanical ventilation, mortality within 28 days) in adult hospitalised patients [62]. There are several case reports where immunocompetent and immunocompromised patients are successfully treated with acyclovir for herpes simplex virus pneumonia $[63,64]$. However, different studies also showed that HSV-1 may be a marker for underlying clinical conditions, rather than a cause of mortality [65]. For cytomegalovirus (CMV), quantification of viral load in bronchoalveolar lavage samples seems to be useful in diagnosing CMV pneumonia, but a viral DNA threshold has not been established [66]. The same problems with producing quantitative results, as mentioned in the beginning of this paragraph, apply here [44]. Moreover, since the amount of recovered epithelial lining fluid can vary considerably, the detected viral load can vary accordingly [65]. Hematopoietic stem cell recipients with CMV pneumonia who receive early antiviral intervention may have improved outcome [67]. First-line therapy of CMV pneumonia is intravenous ganciclovir [68]. Although valganciclovir is available for oral dosing, it is not typically recommended for HSCT patients with CMV pneumonia [68]. Valganciclovir can be considered for maintenance therapy in lower-risk patients who have demonstrated clinical response to therapy [68]. Possible alternatives for treatment of CMV pneumonia are foscarnet and cidofovir [68].

\section{Can MRVP significantly impact infection control measures?}

The usefulness of molecular diagnostics for implementation of infection control measures is demonstrated by the widespread use of PCR for a numerous amount of pathogens (methicillin-resistant Staphylococcus aureus, Clostridium difficile, norovirus). Because asymptomatic shedding has been reported in a healthy population, it seems intuitive that MRVP could yield similar advantages [69]. Evidently, the impact of detecting respiratory viruses on isolation precautions is related to the necessity for additional infection control measures (next to standard precautions) for these viruses. An overview of respiratory viruses commonly included in MRVP and their recommended isolation precautions is summarized in Table 3 [45, 70-80]. In general, the same isolation precautions are recommended according to the different guidelines.

Two studies report that the results of MRVP affected infection control management, but also mention that logistical problems can limit their effect [35, 37]. Braybrook et al. found that infection control measures of hospitalized children were affected by MRVP in one-quarter of cases, but the value of testing was directly related to the number of isolation rooms available. On the other hand, Cunha et al. studied the infection control implications of MRVP in hospitalized 
adults with influenza-like illness during the 2015 influenza A $\left(\mathrm{H}_{3} \mathrm{~N}_{2}\right)$ outbreak. They were able to provide single rooms for patients with influenza-like illness, but over time were forced to cohort different viral aetiologies.

Studies that compare the effect of rapid MRVP in comparison to standard (molecular) diagnostics appear to show mixed results. Subramony et al. reported an increased use of isolation precautions after implementation of a rapid MRVP, while other studies report a decrease in isolation time [15, 24, 33]. However, there are important differences in design: the study of Subramony compared the rapid MRVP to a combination of PCR (influenza and RSV) and conventional methods. For the study of Rogers (2015) and Van Rijn (2018), a standard MRVP was compared to a rapid MRVP. It may be possible that Subramony et al. compared a MRVP to a conventional method that is less sensitive, leading to a higher recovery rate of RVI and accordingly isolation requirement using a rapid MRVP.

Furthermore, there are different studies that show a beneficial effect of screening for respiratory viruses in immunocompromised patients. Importantly, this population is at risk of developing life-threatening pneumonia. Prolonged viral shedding is reported and might be a catalyser of nosocomial transmission [39]. In HSCT patients for example, the results of MRVP have shown to be useful for identifying asymptomatically infected patients with viral shedding [34, 38]. Baier et al. more specifically implemented a screening program for all patients lacking respiratory symptoms who were hospitalized on an adult and a paediatric haemato-oncological ward. The seasonal screening program enabled them to identify 23 (out of 251 tested patients) RSV or influenza infections in asymptomatic patients in a 4-month period. The authors concluded that this screening program proved useful for identifying asymptomatically infected patients with viral shedding, thus reducing the risk of transmission and potential nosocomial clusters of RSV and influenza virus on haemato-oncological wards. Kakiuchi et al. performed a 2-year prospective cohort surveillance study of symptomatic and asymptomatic RVI in hospitalized HSCT patients. For asymptomatic patients, the samples were subjected to cell culture-based viral isolation. If no pathogens were found with cell culture, the samples were then further tested with a MRVP. Symptomatic patients were tested using the MRVP. The parainfluenza virus type 3 (PIV3) accounted for $71 \%$ of the cases of RVI. Some PIV3 infections were asymptomatic and involved a longer virus-shedding period. The PIV3 was often detected from samples taken before the onset of respiratory disease and infections were attributed to nosocomial transmission. PIV3 infections before engraftment will more likely result in the development of lower respiratory tract infections and worse outcomes. Therefore, the authors recommend real-time monitoring of respiratory viral infections in the HSCT ward among patients with or without respiratory symptoms for the prevention of nosocomial RVI, especially of PIV3 infections.

Finally, MRVP can play a potential role in directing the public health response. For example, Shaw et al. highlighted the importance of syndromic surveillance in directing the public health response to an enterovirus D68 epidemic [40]. Early detection of the virus in the community informed decisions to activate hospital preparedness and emergency response teams and promoted proactive community and physician education aimed at avoiding unnecessary emergency department visits.

In general, all these studies led to a more accurate use of infection control measures by detecting unidentified pathogens or stopping isolation precautions in case of a negative MRVP result.

This study has several limitations. Although all studies cited were published in peer reviewed journals, we did not assess the quality of the different studies. We used an extensive search string on the PubMed and Embase database, but it seems likely that not all relevant articles were withheld. Also, because the selection of articles was performed by one person, selection bias is possible.

\section{Conclusion}

MRVP recently have become part of routine diagnostic testing. Therefore, their impact with respect to antibiotic therapy use, antiviral treatment, and infection control is not fully understood. The effect on antibiotic therapy seems promising in combatting the global problem of antibiotic misuse and associated development of resistance. This effect might not be present in all populations and seems to be positively influenced by several factors: presence of an active antimicrobial stewardship program, low likelihood of a bacterial infection, and a short time to result.

The ability of MRVP to have an impact on antiviral treatment of RVI is most obvious for influenza. In contrast to the effect on antibiotic therapy, this effect seems to be less dependent on different factors (e.g., active antimicrobial stewardship, short time to result). Regarding treatment of RVI other than influenza and RSV, few options are available. Several studies report on a positive effect of antiviral therapy, although high-quality studies are needed in the future to further establish which drug, dose, route of administration, and indication should be used for these RVI.

With regard to infection control, the potential impact of MRVP is high because of the need of additional isolation precautions for many RVI. However, logistical problems can occur in the winter season. This impact is often more pronounced in an immunocompromised population, since RVI in this population are potentially life threatening and prolonged viral shedding occurs. Finally, MRVP have the 
potential to adequately direct the public health response in case of an epidemic.

Author contribution Each author contributed to the article. Jense Wils prepared the manuscript. Veroniek Saegeman and Annette Schuermans reviewed the manuscript. All authors have approved the final article.

Data availability Not applicable

Code availability Not applicable

\section{Declarations}

Ethics approval Not applicable

Consent to participate Not applicable

Consent for publication All authors have approved the final article.

Conflict of interest The authors declare no competing interests

\section{References}

1. Murray CJ, Barber RM, Foreman KJ, Ozgoren AA, Abd-Allah F, Abera SF, Aboyans V, Abraham JP, Abubakar I, Abu-Raddad LJ (2015) Global, regional, and national disability-adjusted life years (DALYs) for 306 diseases and injuries and healthy life expectancy (HALE) for 188 countries, 1990-2013: quantifying the epidemiological transition. Lancet 386(10009):2145-2191

2. Martin LJ, Im C, Dong H, Lee BE, Talbot J, Meurer DP, Mukhi SN, Drews SJ, Yasui Y (2017) Influenza-like illness-related emergency department visits: Christmas and New Year holiday peaks and relationships with laboratory-confirmed respiratory virus detections, Edmonton, Alberta, 2004-2014. Influenza Other Respir Viruses 11(1):33-40

3. Rolfes MA, Foppa IM, Garg S, Flannery B, Brammer L, Singleton JA, Burns E, Jernigan D, Olsen SJ, Bresee J (2018) Annual estimates of the burden of seasonal influenza in the United States: a tool for strengthening influenza surveillance and preparedness. Influenza Other Respir Viruses 12(1):132-137

4. Beckmann C, Hirsch HH (2016) Comparing luminex NxTAGrespiratory pathogen panel and RespiFinder-22 for multiplex detection of respiratory pathogens. J Med Virol 88(8):1319-1324

5. Chen JH, Lam H-Y, Yip CC, Wong SC, Chan JF, Ma ES, Cheng VC, Tang BS, Yuen K-Y (2016) Clinical evaluation of the new high-throughput luminex NxTAG respiratory pathogen panel assay for multiplex respiratory pathogen detection. J Clin Microbiol 54(7):1820-1825

6. Nickbakhsh S, Thorburn F, Von Wissmann B, McMenamin J, Gunson R, Murcia P (2016) Extensive multiplex PCR diagnostics reveal new insights into the epidemiology of viral respiratory infections. Epidemiol Infect 144(10):2064-2076

7. Branche AR, Walsh EE, Vargas R, Hulbert B, Formica MA, Baran A, Peterson DR, Falsey AR (2015) Serum procalcitonin measurement and viral testing to guide antibiotic use for respiratory infections in hospitalized adults: a randomized controlled trial. J Infect Dis 212(10):1692-1700

8. Busson L, Bartiaux M, Brahim S, Konopnicki D, Dauby N, Gérard M, De Backer P, Van Vaerenbergh K, Mahadeb B, Mekkaoui L, De Foor M, Wautier M, Vandenberg O, Mols P, Levy J, Hallin M
(2019) Contribution of the filmarray respiratory panel in the management of adult and pediatric patients attending the emergency room during 2015-2016 influenza epidemics: an interventional study. Int J Infect Dis 83:32-39

9. Goriacko P, Saiman L, Zachariah P (2018) Antibiotic use in hospitalized children with respiratory viruses detected by multiplex polymerase chain reaction. Pediatr Infect Dis J 37(5):443-446

10. Kitano T, Nishikawa H, Suzuki R, Onaka M, Nishiyama A, Kitagawa D, Oka M, Masuo K, Yoshida S (2019) The impact analysis of a multiplex PCR respiratory panel for hospitalized pediatric respiratory infections in Japan. J Infect Chemother 26(1):82-85

11. Lowe CF, Payne M, Puddicombe D, Mah A, Wong D, Kirkwood A, Hull MW, Leung V (2017) Antimicrobial stewardship for hospitalized patients with viral respiratory tract infections. Am J Infect Control 45(8):872-875

12. Mulpuru S, Aaron SD, Ronksley PE, Lawrence N, Forster AJ (2015) Hospital resource utilization and patient outcomes associated with respiratory viral testing in hospitalized patients. Emerg Infect Dis 21(8):1366-1371

13. Schulert GS, Lu Z, Wingo T, Tang YW, Saville BR, Hain PD (2013) Role of a respiratory viral panel in the clinical management of pediatric inpatients. Pediatr Infect Dis J 32(5):467-472

14. Semret M, Schiller I, Jardin BA, Frenette C, Loo VG, Papenburg J, McNeil SA, Dendukuri N (2017) Multiplex respiratory virus testing for antimicrobial stewardship: a prospective assessment of antimicrobial use and clinical outcomes among hospitalized adults. J Infect Dis 216(8):936-944

15. Subramony A, Zachariah P, Krones A, Whittier S, Saiman L (2016) Impact of multiplex polymerase chain reaction testing for respiratory pathogens on healthcare resource utilization for pediatric inpatients. J Pediatr 173:196-201.e192

16. Yee C, Suarthana E, Dendukuri N, Nicolau I, Semret M, Frenette $\mathrm{C}$ (2016) Evaluating the impact of the multiplex respiratory virus panel polymerase chain reaction test on the clinical management of suspected respiratory viral infections in adult patients in a hospital setting. Am J Infect Control 44(11):1396-1398

17. Andrews D, Chetty Y, Cooper BS, Virk M, Glass SK, Kelly PA, Sudhanva M, Jeyaratnam D (2017) Multiplex PCR point of care testing versus routine, laboratory-based testing in the treatment of adults with respiratory tract infections: a quasi-randomised study assessing impact on length of stay and antimicrobial use. BMC Infect Dis 17(1):671

18. Brendish NJ, Malachira AK, Armstrong L, Houghton R, Aitken S, Nyimbili E, Ewings S, Lillie PJ, Clark TW (2017) Routine molecular point-of-care testing for respiratory viruses in adults presenting to hospital with acute respiratory illness (ResPOC): a pragmatic, open-label, randomised controlled trial. Lancet Respir Med 5(5):401-411

19. Brittain-Long R, Westin J, Olofsson S, Lindh M, Andersson L (2011) Access to a polymerase chain reaction assay method targeting 13 respiratory viruses can reduce antibiotics: a randomised, controlled trial. BMC Med 9

20. Echavarria M, Marcone DN, Querci M, Seoane A, Ypas M, Videla C, O'Farrell C, Vidaurreta S, Ekstrom J, Carballal G (2018) Clinical impact of rapid molecular detection of respiratory pathogens in patients with acute respiratory infection. J Clin Virol: the official publication of the Pan American Society for Clinical Virology 108:90-95

21. Weiss ZF, Cunha CB, Chambers AB, Carr AV, Rochat C, RaglowDefranco M, Parente DM, Angus A, Mermel LA, Sivaprasad L (2019) Opportunities revealed for antimicrobial stewardship and clinical practice with implementation of a rapid respiratory multiplex assay. J Clin Microbiol 57(10):e00861-e819

22. Keske Ş, Ergönül Ö, Tutucu F, Karaaslan D, Palaoğlu E, Can F (2018) The rapid diagnosis of viral respiratory tract infections 
and its impact on antimicrobial stewardship programs. Eur J Clin Microbiol Infect Dis 37(4):779-783

23. Rappo U, Schuetz AN, Jenkins SG, Calfee DP, Walsh TJ, Wells MT, Hollenberg JP, Glesby MJ (2016) Impact of early detection of respiratory viruses by multiplex PCR assay on clinical outcomes in adult patients. J Clin Microbiol 54(8):2096-2103

24. Rogers BB, Shankar P, Jerris RC, Kotzbauer D, Anderson EJ, Watson JR, O'Brien LA, Uwindatwa F, McNamara K, Bost JE (2015) Impact of a rapid respiratory panel test on patient outcomes. Arch Pathol Lab Med 139(5):636-641

25. Moradi T, Bennett N, Shemanski S, Kennedy K, Schlachter A, Boyd S (2019) Use of procalcitonin and a respiratory polymerase chain reaction panel to reduce antibiotic use via an EMR alert. Clinical infectious diseases: an official publication of the Infectious Diseases Society of America

26. Srinivas P, Rivard KR, Pallotta AM, Athans V, Martinez K, Loutzenheiser S, Lam SW, Procop GW, Richter SS, Neuner EA (2019) Implementation of a stewardship initiative on respiratory viral PCR-based antibiotic deescalation. Pharmacotherapy 39(6):709-717

27. File TM, Politis P, Tan MJ, Kallstrom G (2017) Effect of rapid molecular diagnostic testing and antimicrobial stewardship on antimicrobial therapy of respiratory infections. Open Forum Infect Dis 4:S628-S629

28. Timbrook T, Maxam M, Bosso J (2015) Antibiotic discontinuation rates associated with positive respiratory viral panel and low procalcitonin results in proven or suspected respiratory infections. Infect Dis Ther 4(3):297-306

29. Saarela E, Tapiainen T, Kauppila J, Pokka T, Uhari M, Kauma H, Renko M (2019) Impact of multiplex respiratory virus testing on antimicrobial consumption in adults in acute care: a randomized clinical trial. Clin Microbiol Infect: the official publication of the European Society of Clinical Microbiology and Infectious Diseases

30. Shengchen D, Gu X, Fan G, Sun R, Wang Y, Yu D, Li H, Zhou F, Xiong Z, Lu B (2019) Evaluation of a molecular point-of-care testing for viral and atypical pathogens on intravenous antibiotic duration in hospitalized adults with lower respiratory tract infection: a randomized clinical trial. Clin Microbiol Infect 25(11):1415-1421

31. Krantz EM, Zier J, Stohs E, Ogimi C, Sweet A, Marquis S, Klaassen J, Pergam SA, Liu C (2020) Antibiotic prescribing and respiratory viral testing for acute upper respiratory infections among adult patients at an ambulatory cancer center. Clin Infect Dis 70(7): 1421-1428

32. Kadatz M, Payne M, Kiaii M, Romney MG, Karakas L, Lawson T, Marchuk S, Gill J, Lowe CF (2020) Utility of rapid influenza molecular testing in an outpatient hemodialysis unit: a prospective cohort study. Can J Kidney Health Dis 7:2054358120907816

33. van Rijn AL, Nijhuis RH, Bekker V, Groeneveld GH, Wessels E, Feltkamp MC, Claas EC (2018) Clinical implications of rapid ePlex ${ }^{\circledR}$ respiratory pathogen panel testing compared to laboratory-developed real-time PCR. Eur J Clin Microbiol Infect Dis 37(3):571-577

34. Baier C, Linderkamp C, Beilken A, Thol F, Heuser M, Ebadi E, Ganzenmueller T, Heim A, Bange F-C (2018) Influenza and respiratory syncytial virus screening for the detection of asymptomatically infected patients in hematology and oncology. GMS Hyg Infect Control 13:doc08

35. Braybrook S, Gray J (2018) Value of widespread use of multiplex PCR for diagnosis of viral respiratory tract infections in children. J Hosp Infect 99(1):114-115

36. Poelman R, Der Meer JV, Der Spek CV, Riezebos-Brilman A, Knoester M, Leer-Buter CV, Friedrich AW, Niesters HG (2020) Improved diagnostic policy for respiratory tract infections essential for patient management in the emergency department. Future Microbiol 15(8):623-632

37. Cunha BA, Connolly JJ, Musta AC, Abruzzo E (2015) Infection control implications of protracted lengths of stay with noninfluenza viral influenza-like illnesses in hospitalized adults during the 2015 influenza a (H3N2) epidemic. Infect Control Hosp Epidemiol 36(11): 1368-1370

38. Kakiuchi S, Tsuji M, Nishimura H, Wang L, Takayama-Ito M, Kinoshita H, Lim CK, Taniguchi S, Oka A, Mizuguchi M, Saijo M (2018) Human parainfluenza virus type 3 infections in patients with hematopoietic stem cell transplants: the mode of nosocomial infections and prognosis. Jpn J Infect Dis 71(2):109-115

39. Lehners N, Tabatabai J, Prifert C, Wedde M, Puthenparambil J, Weissbrich B, Biere B, Schweiger B, Egerer G, Schnitzler P (2016) Long-term shedding of influenza virus, parainfluenza virus, respiratory syncytial virus and nosocomial epidemiology in patients with hematological disorders. PLoS One 11(2):e0148258

40. Shaw J, Welch TR, Milstone AM (2014) The role of syndromic surveillance in directing the public health response to the enterovirus D68 epidemic. JAMA Pediatr 168(11):981-982

41. van Houten CB, Cohen A, Engelhard D, Hays JP, Karlsson R, Moore E, Fernández D, Kreisberg R, Collins LV, de Waal W (2019) Antibiotic misuse in respiratory tract infections in children and adults - a prospective, multicentre study (tailored treatment). Eur J Clin Microbiol Infect Dis 38(3):505-514

42. Barlam TF, Cosgrove SE, Abbo LM, MacDougall C, Schuetz AN, Septimus EJ, Srinivasan A, Dellit TH, Falck-Ytter YT, Fishman NO (2016) Executive summary: implementing an antibiotic stewardship program: guidelines by the Infectious Diseases Society of America and the Society for Healthcare Epidemiology of America. Clin Infect Dis 62(10):1197-1202

43. Jansen RR, Wieringa J, Koekkoek SM, Visser CE, Pajkrt D, Molenkamp R, de Jong MD, Schinkel J (2011) Frequent detection of respiratory viruses without symptoms: toward defining clinically relevant cutoff values. J Clin Microbiol 49(7):2631-2636

44. Charlton CL, Babady E, Ginocchio CC, Hatchette TF, Jerris RC, Li Y, Loeffelholz M, McCarter YS, Miller MB, Novak-Weekley S (2018) Practical guidance for clinical microbiology laboratories: viruses causing acute respiratory tract infections. Clin Microbiol Rev 32(1):e00042-e18

45. Centers for Disease control and prevention (2020) Influenza antiviral medications: summary for clinicians, https://www.cdc.gov/ flu/professionals/antivirals/summary-clinicians.htm\#summary. Cited January 142020

46. Uyeki TM, Bernstein HH, Bradley JS, Englund JA, File TM Jr, Fry AM, Gravenstein S, Hayden FG, Harper SA, Hirshon JM (2019) Clinical practice guidelines by the Infectious Diseases Society of America: 2018 update on diagnosis, treatment, chemoprophylaxis, and institutional outbreak management of seasonal influenza. Clin Infect Dis 68(6):e1-e47

47. Beaird OE, Freifeld A, Ison MG, Lawrence SJ, Theodoropoulos N, Clark NM, Razonable RR, Alangaden G, Miller R, Smith J, Young JAH, Hawkinson D, Pursell K, Kaul DR (2016) Current practices for treatment of respiratory syncytial virus and other non-influenza respiratory viruses in high-risk patient populations: a survey of institutions in the Midwestern Respiratory Virus Collaborative. Transpl Infect Dis 18(2):210-215

48. Hirsch HH, Martino R, Ward KN, Boeckh M, Einsele H, Ljungman P (2013) Fourth European Conference on Infections in Leukaemia (ECIL-4): guidelines for diagnosis and treatment of human respiratory syncytial virus, parainfluenza virus, metapneumovirus, rhinovirus, and coronavirus. Clin Infect Dis 56(2):258-266

49. Xing Y, Proesmans M (2019) New therapies for acute RSV infections: where are we? Eur J Pediatr 178(2):131-138

50. Neofytos D, Ojha A, Mookerjee B, Wagner J, Filicko J, Ferber A, Dessain S, Grosso D, Brunner J, Flomenberg N (2007) Treatment 
of adenovirus disease in stem cell transplant recipients with cidofovir. Biol Blood Marrow Transplant 13(1):74-81

51. Ljungman P, Ribaud P, Eyrich M, Matthes-Martin S, Einsele H, Bleakley M, Machaczka M, Bierings M, Bosi A, Gratecos N (2003) Cidofovir for adenovirus infections after allogeneic hematopoietic stem cell transplantation: a survey by the infectious diseases working party of the European group for blood and marrow transplantation. Bone Marrow Transplant 31(6):481-486

52. Doan ML, Mallory GB, Kaplan SL, Dishop MK, Schecter MG, McKenzie ED, Heinle JS, Elidemir O (2007) Treatment of adenovirus pneumonia with cidofovir in pediatric lung transplant recipients. J Heart Lung Transplant 26(9):883-889

53. Symeonidis N, Jakubowski A, Pierre-Louis S, Jaffe D, Pamer E, Sepkowitz K, O'Reilly R, Papanicolaou G (2007) Invasive adenoviral infections in T-cell-depleted allogeneic hematopoietic stem cell transplantation: high mortality in the era of cidofovir. Transpl Infect Dis 9(2):108-113

54. Haas LE, Thijsen SF, Van Elden L, Heemstra KA (2013) Human metapneumovirus in adults. Viruses 5(1):87-110

55. Nichols WG, Corey L, Gooley T, Davis C, Boeckh M (2001) Parainfluenza virus infections after hematopoietic stem cell transplantation: risk factors, response to antiviral therapy, and effect on transplant outcome. Blood J Am Soc Hematol 98(3):573-578

56. Elizaga J, Olavarria E, Apperley J, Goldman J, Ward K (2001) Parainfluenza virus 3 infection after stem cell transplant: relevance to outcome of rapid diagnosis and ribavirin treatment. Clin Infect Dis 32(3):413-418

57. Chakrabarti S, Collingham K, Holder K, Oyaide S, Pillay D, Milligan D (2000) Parainfluenza virus type 3 infections in hematopoetic stem cell transplant recipients: response to ribavirin therapy. Clin Infect Dis 31(6):1516-1518

58. Casey J, Morris K, Narayana M, Nakagaki M, Kennedy G (2013) Oral ribavirin for treatment of respiratory syncitial virus and parainfluenza 3 virus infections post allogeneic haematopoietic stem cell transplantation. Bone Marrow Transplant 48(12):1558-1561

59. Salvatore M, Satlin MJ, Jacobs SE, Jenkins SG, Schuetz AN, Moss RB, Van Besien K, Shore T, Soave R (2016) DAS181 for treatment of parainfluenza virus infections in hematopoietic stem cell transplant recipients at a single center. Biol Blood Marrow Transplant 22(5):965-970

60. Stockman LJ, Bellamy R, Garner P (2006) SARS: systematic review of treatment effects. PLoS Med 3(9)

61. Omrani AS, Saad MM, Baig K, Bahloul A, Abdul-Matin M, Alaidaroos AY, Almakhlafi GA, Albarrak MM, Memish ZA, Albarrak AM (2014) Ribavirin and interferon alfa-2a for severe Middle East respiratory syndrome coronavirus infection: a retrospective cohort study. Lancet Infect Dis 14(11):1090-1095

62. Costa C, Sidoti F, Saldan A, Sinesi F, Balloco C, Simeone S, Lorusso M, Mantovani S, Merlino C, Solidoro P (2012) Clinical impact of HSV-1 detection in the lower respiratory tract from hospitalized adult patients. Clin Microbiol Infect 18(8):E305-E307

63. Mills B, Ratra A, El-Bakush A, Kambali S, Nugent K (2014) Herpes simplex pneumonia in an immunocompetent patient with progression to organizing pneumonia. J Investig Med High Impact Case Rep 2(2)

64. Traen S, Bochanen N, Ieven M, Schepens T, Bruynseels P, Verbrugghe W, Jorens PG (2014) Is acyclovir effective among critically ill patients with herpes simplex in the respiratory tract? J Clin Virol 60(3):215-221

65. Tachikawa R, Tomii K, Seo R, Nagata K, Otsuka K, Nakagawa A, Otsuka K, Hashimoto H, Watanabe K, Shimizu N (2014) Detection of herpes viruses by multiplex and real-time polymerase chain reaction in bronchoalveolar lavage fluid of patients with acute lung injury or acute respiratory distress syndrome. Respiration; International Review Of Thoracic Diseases 87(4):279-286

66. Jain S (2017) Epidemiology of viral pneumonia. Clin Chest Med 38(1):1-9

67. Machado C, Dulley FL, Boas L, Castelli J, Macedo M, Silva R, Pallota R, Saboya R, Pannuti C (2000) CMV pneumonia in allogeneic BMT recipients undergoing early treatment or pre-emptive ganciclovir therapy. Bone Marrow Transplant 26(4):413-417

68. Travi G, Pergam SA (2014) Cytomegalovirus pneumonia in hematopoietic stem cell recipients. J Intensive Care Med 29(4):200-212

69. Shaman J, Morita H, Birger R, Boyle M, Comito D, Lane B, Ligon C, Smith H, Desalle R, Planet P (2018) Asymptomatic summertime shedding of respiratory viruses. J Infect Dis 217(7):1074-1077

70. Centers for Disease control and prevention (2020) Infection control guidance for healthcare professionals about coronavirus, https://www.cdc.gov/coronavirus/2019-nCoV/hcp/infection-contr ol.html. Cited February 25, 2020

71. Centers for Disease control and prevention (2020) Prevention strategies for seasonal influenza in healthcare settings, https:// www.cdc.gov/flu/professionals/infectioncontrol/healthcaresetti ngs.html. Cited January 14, 2020

72. World Health organisation (2020) Infection prevention and control during health care when novel coronavirus $(\mathrm{nCoV})$ infection is suspected. Interim guidance, https://www.who.int/publications/i/ item/infection-prevention-and-control-during-health-care-whennovel-coronavirus-(ncov)-infection-is-suspected-20200125. Cited January 25, 2020

73. World Health Organisation (2020) Infection prevention and control during health care for probable or confirmed cases of Middle East respiratory syndrome coronavirus (MERS-CoV) infection. Interim guidance. Updated October 2019, https://www.who.int/csr/disease/ coronavirus_infections/ipc-mers-cov/en/. Cited January 25, 2020

74. World Health Organisation (2020) Hospital infection control guidance for severe acute respiratory syndrome (SARS), https://www.who.int/ ihr/lyon/surveillance/infectioncontrol/en/. Cited February 26, 2020

75. Landelijke Coördinatie Infectieziektebestrijding (2020) MERSCoV Richtlijn, https://lci.rivm.nl/richtlijnen/merscov. Cited February 26, 2020

76. Landelijke Coördinatie Infectieziektebestrijding (2020) COVID19 Richtlijn, https://lci.rivm.nl/richtlijnen/covid-19. Cited February 26,2020

77. Landelijke Coördinatie Infectieziektebestrijding (2020) RSVinfectie Richtlijn, https://lci.rivm.nl/richtlijnen/rsv-infectie. Cited February 26, 2020

78. Landelijke Coördinatie Infectieziektebestrijding (2020) Adenovirusinfecties Richtlijn, https://lci.rivm.nl/richtlijnen/adenovirus infecties. Cited February 26, 2020

79. Landelijke Coördinatie Infectieziektebestrijding (2020) Influenza Richtlijn, https://lci.rivm.nl/richtlijnen/influenza. Cited February 26, 2020

80. Siegel J, Rhinehart, E., Jackson, M., Chiarello, L. (2007) Healthcare Infection Control Practices Advisory Committee. Guideline for isolation precautions: preventing transmission of infectious agents in healthcare settings., https://www.cdc.gov/infectionc ontrol/pdf/guidelines/isolation-guidelines-H.pdf. Cited January 14,2020

Publisher's note Springer Nature remains neutral with regard to jurisdictional claims in published maps and institutional affiliations. 